\title{
Equilibrium and Kinetic Modelling of Adsorption: Evaluating the Performance of an Adsorbent in Softening Water for Irrigation and Animal Consumption
}

\author{
Ferreira, A. S.; Mota, A. A.; Oliveira, A. M.; Rodrigues, F. I. L.; Pacífico, S. \\ N.; Silva, J. E.;* Abagaro, B. T. O.; Saraiva, G. D.; Castro, A. J. R.; Teixeira, \\ R. N. P.; Sousa Neto, V. O.*
}

Rev. Virtual Quim., 2019, 11 (6), 1752-1766. Data de publicação na Web: 2 de janeiro de 2020

http://rvq.sbq.org.br

Modelagem de Equilíbrio e Cinética de Adsorção: Avaliação do Desempenho do Adsorvente no Abrandamento da Água para Irrigação e o Consumo de Animais

Resumo: O bagaço de coco, um desperdício sólido agrícola foi utilizado como biossorvente para remoção de dureza após tratamento alcalinizado. A adsorção de $\mathrm{Ca}$ (II) foi estudada a pH 6,8. A análise das isotermas pelo modelo não-linear mostrou que os dados experimentais foram melhor descritos pelo modelo de Temkin, com menor valor $\chi 2$ obtido. As capacidades máximas de adsorção pelo modelo de Langmuir foi de $30,20 \mathrm{mg} \cdot \mathrm{g}^{-1}$. Os resultados utilizando o método não linear e linear mostraram baixa discrepância entre eles para o estudo de equilíbrio. Os resultados mostram que o adsorvente de CHA pode ser aplicado para a remoção da dureza das águas residuais.

Resumo: Adsorção; mecanismo; cinética; dureza.

\begin{abstract}
Coconut bagasse, an agricultural solid waste, was used as a biosorbent for the removal of hardness after alkali treatment. The adsorption of $\mathrm{Ca}(\mathrm{II})$ was studied at $\mathrm{pH} 6.8$. The analysis of the isotherms by the nonlinear model showed that the experimental data were best described by the Temkin model, which obtained a lower $\chi 2$ value. The maximum adsorption capacity by the Langmuir model was $30.20 \mathrm{mg} . \mathrm{g}^{-1}$. The results using non-linear and linear methods to study equilibrium showed low discrepancy between them. The results show that the CHA adsorbent can be used for the removal of hardness from wastewater.
\end{abstract}

Keywords: Adsorption; mechanism; kinetic; hardness.

\footnotetext{
* State University of Ceará (UECE-CECITEC), Department of Chemistry, Street Sólon Medeiros, S/N, CEP 63660-000, Tauá-CE, Brazil.

M jose.eduardo@aluno.uece.br; vicente.neto@uece.br DOI: $\underline{10.21577 / 1984-6835.20190123}$
} 


\title{
Equilibrium and Kinetic Modelling of Adsorption: Evaluating the Performance of Adsorbent in Softening Water for Irrigation and Animal Consumption
}

\author{
Aline S. Ferreira, ${ }^{a}$ Antonébia A. Mota, ${ }^{a}$ Aldayr M. Oliveira, ${ }^{a}$ Francisco I. L. \\ Rodrigues, ${ }^{a}$ Sara N. Pacífico, ${ }^{a}$ José E. da Silva, ${ }^{a, *}$ Bruno T. O. Abagaro, ${ }^{c, d}$ \\ Gilberto D. Saraiva, ${ }^{b}$ Antonio J. R. de Castro, ${ }^{b}$ Raimundo N. P. Teixeira, ${ }^{e}$ \\ Vicente O. Sousa Neto ${ }^{\mathrm{a}, *}$ \\ a State University of Ceará (UECE-CECITEC), Department of Chemistry, Street. Sólon Medeiros, \\ S/N, CEP 63660-000, Tauá-CE, Brazil. \\ b State University of Ceará (UECE-FECLESC), Department of Physics, Street José de Queiroz, \\ 2554, CEP 63900-000 Planalto Universitário, Quixadá-Ceará, Brazil. \\ 'State University of Ceará (UECE-FAFIDAM), Department of Physics, Street Dom Aureliano \\ Matos, CEP 62.930-000, João XXIII, Limoeiro do Norte-CE, Brazil

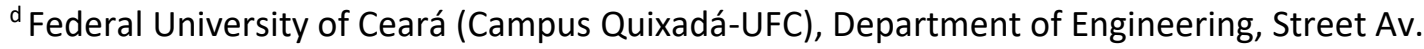 \\ José de Freitas Queiroz 5003, CEP 63902-580, Cedro-Quixadá-CE, Brazil. \\ e Regional University of Cariri, Department of Biological Chemistry, Street Coronel Antônio Luis, \\ CEP 63000-100, Pimenta, Crato-CE, Brazil. \\ jose.eduardo@aluno.uece.br; vicente.neto@uece.br
}

Recebido em 28 de março de 2019. Aceito para publicação em 13 de setembro de 2019

1. Introduction

2. Materials and Methods

2.1. Adsorbent

2.2. Alkaline Treatment of Raw Coconut Husk (CHA)

2.3. Ca (II) Synthetic Solutions

2.4. Equilibrium Study

2.5. Zero Potential Charge Analysis

\section{Results and Discussion}

\subsection{Zeta Potential}

3.2. Equilibrium Study

3.3. Qui-square $\left(\chi^{2}\right)$ : Analysis of Nonlinear Regression

\section{Conclusion}




\section{Introduction}

Water hardness is a traditional measure of the capacity of water to react with soap. Hard water requires considerably more soap to produce a lather. Hard water often produces a noticeable deposit of precipitate (e.g. insoluble metals, soaps or salts) in containers, including "bathtub ring". It is not caused by a single substance but by a variety of dissolved polyvalent metallic ions, predominantly calcium and magnesium cations although other cations (e.g. aluminium, barium, iron, manganese, strontium, and zinc) also contribute. Hardness is most commonly expressed as milligrams of calcium carbonate equivalents per litre. ${ }^{1}$ Water containing calcium carbonate at concentrations below $60 \mathrm{mg} . \mathrm{L}^{-1}$ is generally considered as soft; 60 $120 \mathrm{mg} \cdot \mathrm{L}^{-1}$, moderately hard; $120-180 \mathrm{mg} \cdot \mathrm{L}^{-1}$, hard; and more than $180 \mathrm{mg} \cdot \mathrm{L}^{-1}$, very hard. ${ }^{2}$ Although hardness is caused by cations, it may also be discussed in terms of carbonate (temporary) and non-carbonate (permanent) hardness. Calcium and magnesium are the fifth and the eighth species in order of abundance in natural waters, respectively, with concentrations ranging from a few to hundreds of $\mathrm{mg} \mathrm{L}^{-1}$ depending on the source and the treatment to which the water has been subjected.

Hard water is not a health hazard. In fact, the National Research Council (National Academy of Sciences) states that hard drinking water generally contributes a small amount toward the total calcium and magnesium needed in the human diet. The Council further states that in some instances, where dissolved calcium and magnesium are very high, water could be a major contributor of calcium and magnesium to the diet. ${ }^{3}$

Much research has been done on the relationship between water hardness and cardiovascular disease mortality. While numerous studies suggest a correlation between hard water and lower cardiovascular disease mortality, no firm conclusions have been drawn. The National Research Council has recommended further studies be conducted. The World Health Organization (WHO) is attempting to coordinate a worldwide study on the effect on cardiovascular disease before and after changes in water supply hardness.

Among the different technologies which need the addition chemicals for water softening are chemical precipitation and ion exchange, and there are those methods which do not need added chemicals; these include reverse osmosis, electrodialysis, nanofiltration, crystallization, distillation, and evaporation. ${ }^{1,4-8}$ These techniques have some problems such as increased sludge, permanent water hardness, water salts like sodium, annual high operation costs, and sediment formation on membranes which requires an effluent post treatment and disposal of residual sludge. ${ }^{9-}$ 12 Recently, growing demand for highquality water has justified the development of modern and low cost technologies for softening hard and very hard water. ${ }^{4,5,11}$ One of these techniques is the adsorption process, which is being used for the removal of ions, organic matter, dyes, surfactants, oil, and heavy metals from aqueous environments. ${ }^{13-16}$ Studies have shown that alkali treatment of cellulose leads to a change in structure, facilitating its solubilization. In this context, coconut (Cocos nucifera) shell, a waste lignocellulosic material, contains various polar functional groups such as carboxylic and phenolic acid groups that show affinity for metal complexation. ${ }^{17}$

In this study, three adsorption models often reported in the literature were tested to provide the best description of $\mathrm{Ca}$ (II) adsorption, namely Langmuir, Freundlinch, and Temkin. It should be noted that for Langmuir, Freundlich, and Temkin models, the set of isotherm parameters was calculated not only by linearization but also in nonlinear forms. For the linear models, the coefficient of determination $\left(R^{2}\right)$ is widely used in assessment of isotherm accuracies and is commonly determined by the least squares method. For the nonlinear forms, the various constants of these models were calculated by the error function qui-square $\left(\chi^{2}\right)$ using the solver add-in from Microsoft's spreadsheet, Excel (Microsoft, 2007). 


\section{Materials and Methods}

\subsection{Adsorbent}

Raw coconut husk $(\mathrm{RCH})$ was obtained from EMBRAPA - Agroindústria Tropical (CNPAT) (Fortaleza, CE-BRAZIL). The material was first dried in sunlight and then cut into small pieces. The coconut shells were ground and screened to prepare 59 to 150 mesh size particles. The fractions were further dried in an oven with air circulation at $60^{\circ} \mathrm{C}$ for a period of $24 \mathrm{~h}$.

\subsection{Alkaline treatment of raw coconut husk (CHA)}

The coconut shell powder was treated with $\mathrm{NaOH}(0.1 \mathrm{M})$ and heated at $70{ }^{\circ} \mathrm{C}$ for $1 \mathrm{~h}$ under continuous stirring. The solid material was filtered, washed several times with distilled water, and dried at $60^{\circ} \mathrm{C}$ for $48 \mathrm{~h}$. It was named CHA.

\subsection{Ca (II) synthetic solutions}

A stock solution of $\mathrm{Ca}$ (II) $\left(500 \mathrm{mg}^{-1}\right.$ ) was prepared by dissolving $\mathrm{CaCO}_{3}$ (analytical reagent) in deionized water, and it was further diluted to the initial concentrations ( 40 to $500 \mathrm{mg} \cdot \mathrm{L}^{-1}$ ).

\subsection{Equilibrium study}

A series of batch experiments was conducted to study equilibrium. A stock solution of $\mathrm{Ca}$ (II) (500 mg. $\mathrm{L}^{-1}, \mathrm{pH}=2.0$, adjusted with $\mathrm{HCl} 10 \mathrm{~mol}^{-\mathrm{L}^{-1}}$ ) was prepared by dissolving $\mathrm{CaCO}_{3}$ (analytical reagent) in deionized water, and it was further diluted to the initial calcium concentrations ( 40 to $500 \mathrm{mg} \cdot \mathrm{L}^{-1}$, $\mathrm{pH}=6.8$ adjusted with $\mathrm{HCl} / \mathrm{NaOH} 0.1 \mathrm{~mol}^{-\mathrm{L}^{-1}}$ ).

Batch adsorption studies were carried out by shaking $100 \mathrm{~mL}$ conical flasks containing 50 $\mathrm{mg}$ of $\mathrm{CHA}$ and $25 \mathrm{~mL}$ of $\mathrm{Ca}$ (II) solution (40 to $\left.500 \mathrm{mg} \cdot \mathrm{L}^{-1}\right)$ on an orbital shaker machine at $150 \mathrm{rpm}$, at ambient temperature $\left(28^{\circ} \mathrm{C}\right)$, and at an initial pH 6.8 (see item 2.4) for 120 min.

The supernatant solution was separated by filtration, and the metal concentrations were measured using a complexometric EDTA titration method. The effect of contact time was studied at predetermined time intervals, and residual $\mathrm{Ca}$ (II) concentrations were analysed. The amount of $\mathrm{Ca}$ (II) adsorbed (mg.g ${ }^{-1}$ ) was calculated using (1):

$$
q_{e}=\frac{(C o-C e) \cdot V}{m}
$$

where $\mathrm{Co}$ and $\mathrm{Ce}$ are the initial and final calcium ion concentrations ( $\left.\mathrm{mg} . \mathrm{L}^{-1}\right)$ in solution respectively, $\mathrm{V}$ is the volume of solution (L), and $\mathrm{m}$ the mass of sorbent (g). For batch kinetic study, the same procedure was followed, and aqueous samples (100 and 500 mg. $\mathrm{L}^{-1}$ ) were taken at pre-set time intervals. The concentration of $\mathrm{Ca}$ (II) was similarly measured. The $\mathrm{Ca}$ (II) uptake at any time, $\mathrm{q}_{\mathrm{t}}$ $\left(\mathrm{mg} \mathrm{g}^{-1}\right)$, was calculated using (2):

$$
q_{t}=\frac{(C o-C t) \cdot V}{m}
$$

where $\mathrm{Ct} \quad\left(\mathrm{mg} \cdot \mathrm{L}^{-1}\right)$ is the liquid-phase concentration of $\mathrm{Ca}$ (II) at any time, $\mathrm{t}(\mathrm{min})$.

\subsection{Zero potential charge analysis}

A Zetasizer Nano ZS instrument (Malvern, GBR) was used to measure the zeta potentials of all of the samples.

\section{Results and Discussion}

\subsection{Zeta potential}

The zeta potential of a surface is the potential that is measured, when one measures the velocity of the particles in an electric field. The point where the plot passes through zero zeta potential is called the isoelectric point, which is very important from a practical consideration. The most important factor that affects zeta potential is the $\mathrm{pH}$. A zeta potential value on its own without a quoted $\mathrm{pH}$ is a virtually meaningless number. Therefore a zeta potential versus $\mathrm{pH}$ curve will often be positive at low $\mathrm{pH}$ and lower or negative at high $\mathrm{pH}^{17}$. The plot of zeta potential versus $\mathrm{pH}$ is shown in Figure (1) with a point of zero zeta potential at a $\mathrm{pH}$ around 2.0 and 4.5 to $\mathrm{CHA}$ and $\mathrm{RCH}$ adsorbents, respectively. 


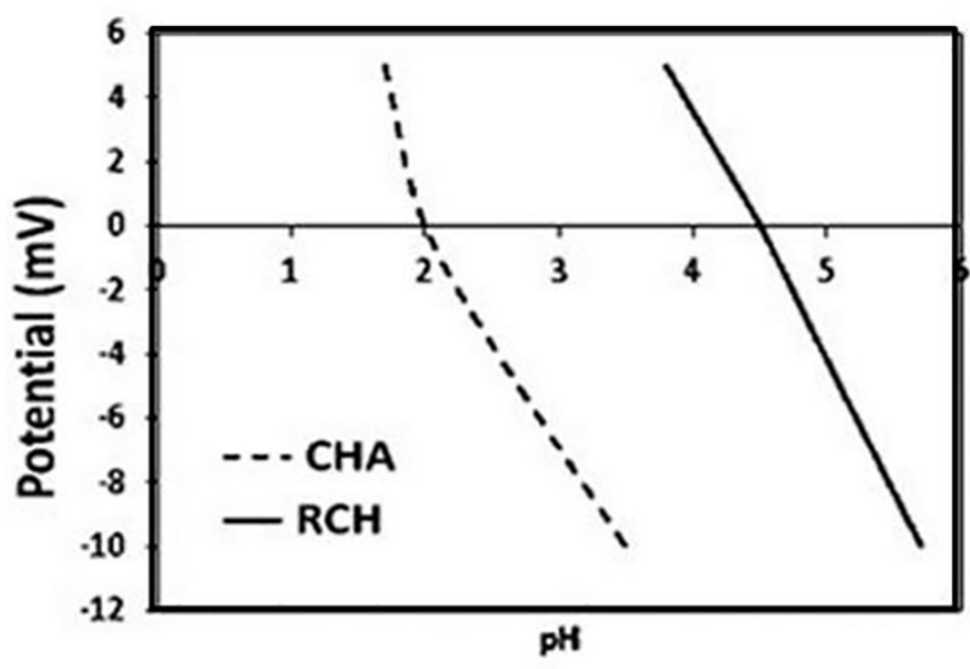

Figure 1. Zeta potential of raw coconut husk $(\mathrm{RCH})$ and coconut husk alkalized $(\mathrm{CHA})$

\subsection{Equilibrium Study}

Adsorption equilibrium is established when the quantity of the specie being adsorbed (qe) is equal to the quantity being desorbed. Then, the equilibrium concentration in solution (Ce) remains constant.

\subsubsection{Langmuir Isotherm}

The most widely used isotherm equation for modelling the biosorption equilibrium data is the Langmuir equation. ${ }^{20,21}$ The Langmuir model suggests that uptake occurs on a homogeneous surface by monolayer sorption without interaction between adsorbed species. This model is described by (3):

$$
\mathrm{q}_{\mathrm{e}}=\frac{\mathrm{q}_{\max } \cdot \mathrm{K}_{\mathrm{L}} \cdot \mathrm{C}_{\mathrm{e}}}{\left(1+\mathrm{K}_{\mathrm{L}} \cdot \mathrm{C}_{\mathrm{e}}\right)}
$$

where qe $\left(\mathrm{mg} \cdot \mathrm{g}^{-1}\right)$ and $\mathrm{Ce}\left(\mathrm{mg} \cdot \mathrm{L}^{-1}\right)$ are the amount of adsorbed per unit mass of sorbent and the metal concentration in solution at equilibrium, respectively; qmax is the maximum amount of the metal per unit mass of sorbent to form a complete monolayer bound on the surface at high $\mathrm{Ce}$. The parameter $\mathrm{K}_{\mathrm{L}}\left(\mathrm{L} \cdot \mathrm{mg}^{-1}\right)$ is a constant related to the affinity of the binding sites. The Langmuir equation can be described in linearized form as shown in (4).

$$
\frac{C_{e}}{q_{e}}=\frac{1}{q_{\max }} C_{e}+\frac{1}{q_{\max K_{L}}}
$$

The Langmuir constants ( $q_{\max }$ and $\mathrm{K}_{\mathrm{L}}$ ) were determined from adsorption isotherm Figure (2a) by the linear method, and they are presented in Table 1. The values of maximum adsorption capacity can be obtained from the slope of the plot of $\mathrm{Ce} / \mathrm{qe}$ versus $\mathrm{Ce}$. The $\mathrm{K}_{\mathrm{L}}$ value was found to be $2.77 \times 10^{-2}$ and $2.87 \times 10^{-2}$

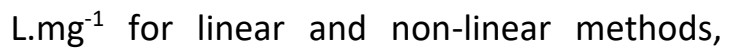
respectively. The maximum adsorption capacity to $\mathrm{CHA}$ adsorbent (qmax) was $\mathbf{3 0 . 3 0}$ $\mathrm{mg} . \mathrm{g}^{-1}$ and $30.20 \mathrm{mg} \cdot \mathrm{g}^{-1}$ using the linear and non-linear methods, respectively. The Figure (2b) shows that theoretical data from the Langmuir linear model has very good agreement with the experiment data. Table 1 shows adsorption capacity values for Ca (II) uptake by $\mathrm{CHA}$ adsorbent.

The essential feature of the Langmuir model can be expressed in terms of a dimensionless constant separation factor ( $R L)$ given by (5):

$$
R_{L}=\frac{1}{1+K_{L} \cdot C_{o}}
$$

where $K_{L}$ is the Langmuir constant $\left(\mathrm{L}^{\mathrm{mg}} \mathrm{mg}^{-1}\right)$ and Co is the initial calcium concentration $\left(\mathrm{mg} \cdot \mathrm{L}^{-1}\right)$. It has been established that for favourable adsorption, $0<\mathrm{R}_{\mathrm{L}}<1$; unfavourable adsorption, $\mathrm{R}_{\mathrm{L}}>1$; linear adsorption, $\mathrm{R}_{\mathrm{L}}=1$; and the adsorption process is irreversible if $R_{L}=0$. In the Figure (3a), it is shown that the values of $R_{L}$ lie between 0.067 and 0.47 for the initial calcium concentration range from 40 to 400 $\mathrm{mg} . \mathrm{L}^{-1}$. This indicates favourable adsorption of 


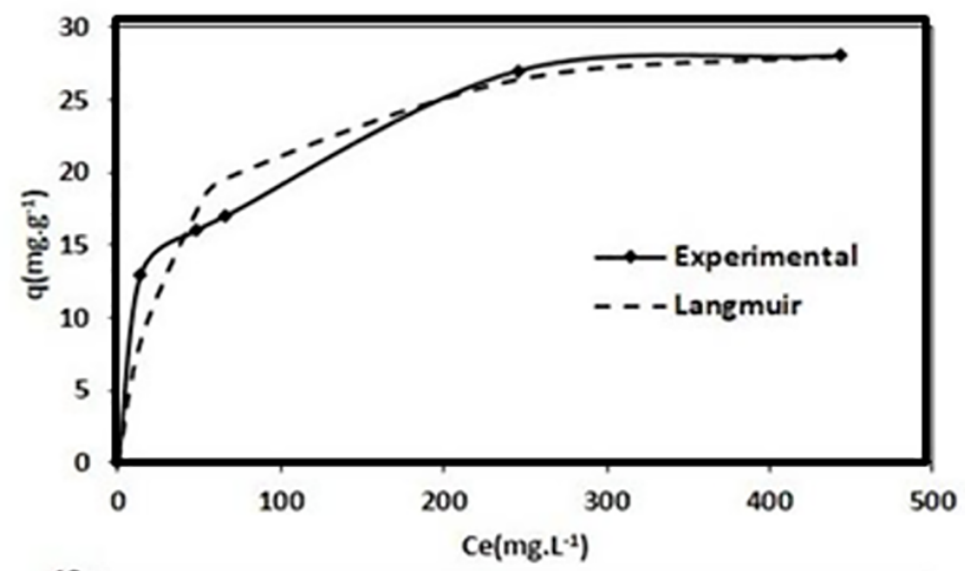

(a)

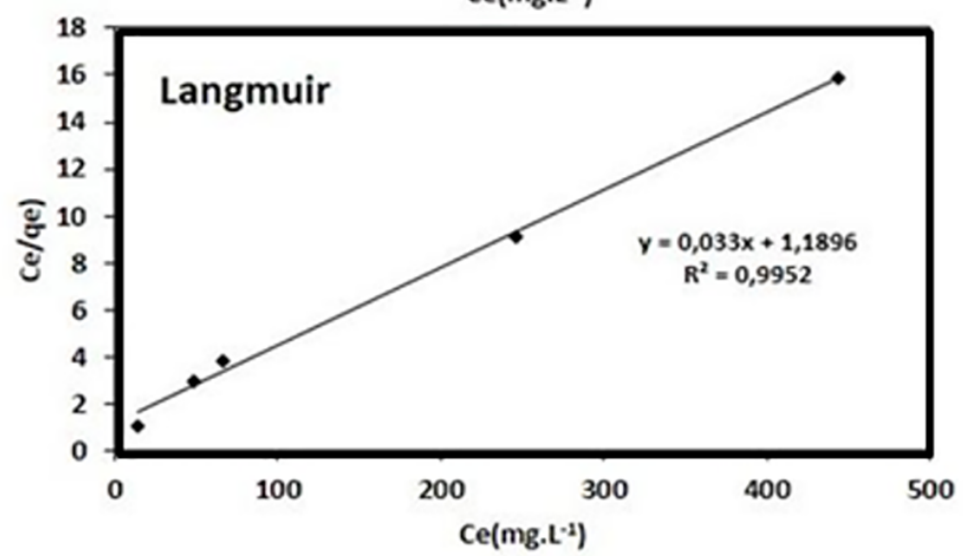

(b)

Figure 2. (a) Theoretical data and experimental data for adsorption of $\mathrm{Ca}$ (II) onto $\mathrm{CHA}$;

(b)Langmuir isotherm linearized; (c) RL values for the adsorption of $\mathrm{Ca}$ (II) onto $\mathrm{CHA}$ adsorbent

calcium onto CHA adsorbent. On the other hand, it is possible write the Langmuir isotherm in dimensionless form as (6). This way it is possible, through the $R_{L}$, to study how the concentration affects the adsorption process.

$$
y=\frac{x}{R_{L}+\left(1-R_{L}\right) x}
$$

where $y=\frac{q_{e}}{q_{\max }}$ and $x=\frac{C_{e}}{C_{o}}$

Figure $3 \mathrm{~b}$ shows the dimensionless Langmuir isotherm for CHA adsorbent. It shows that it has a good adsorption performance in the concentrations studied. This occurs because in the initial calcium concentration the CHA $\left(R_{L}=0.474\right)$ shows a good curve no similar to the linear isotherm case $\left(R_{L}=1\right)$ which indicates good performance in low calcium concentrations. At high concentrations, CHA adsorbent $\left(R_{L}=0.067\right)$ shows a convex shape, indicating a better performance than at low concentrations.

\subsubsection{The Freundlich isotherm model}

The Freundlich equilibrium isotherm equation is an empirical equation used for the description of multilayer adsorption with interaction between adsorbed molecules. It is expressed as (7):

$$
\mathrm{qe}=\mathrm{K}_{\mathrm{F}} \cdot \mathrm{C}_{\mathrm{e}}{ }^{1 / \mathrm{n}}
$$

Applying the property of the logarithms to both sides of the equation, (7) is obtained in linearized form (8):

$$
\ln \left(q_{e}\right)=\ln \left(k_{F}\right)+\frac{1}{n} \ln \left(C_{e}\right)
$$

where qe is the equilibrium amount adsorbed $\left(\mathrm{mg}^{-1} \mathrm{~g}^{-1}\right), \mathrm{Ce}$ the equilibrium concentration of the adsorbate $\left(\mathrm{mg} . \mathrm{L}^{-1}\right), \mathrm{k}_{\mathrm{F}}$ and $\boldsymbol{n}$ are Freundlich constants related to adsorption capacity and intensity of adsorption, respectively. $\mathrm{k}_{\mathrm{T}}$ and $\mathrm{l} / \mathbf{n}$ are related to the sorption intensity which is defined by (9): 


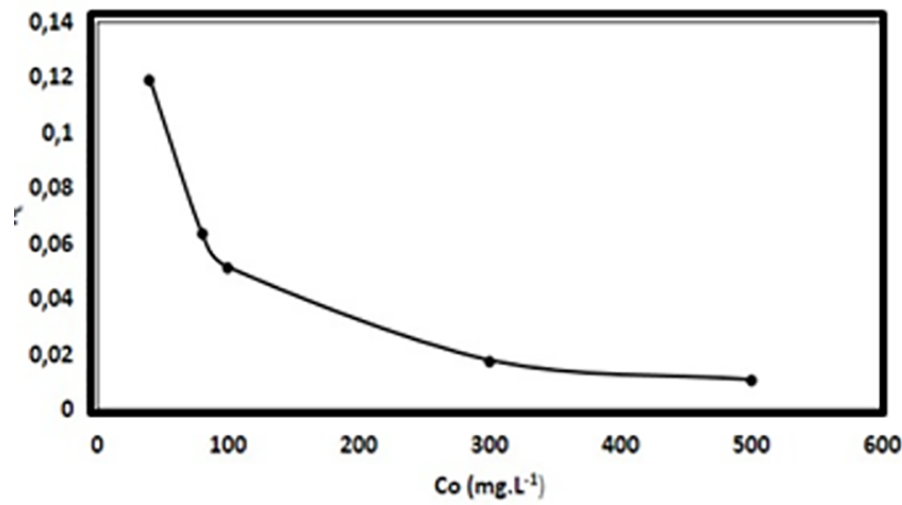

(a)

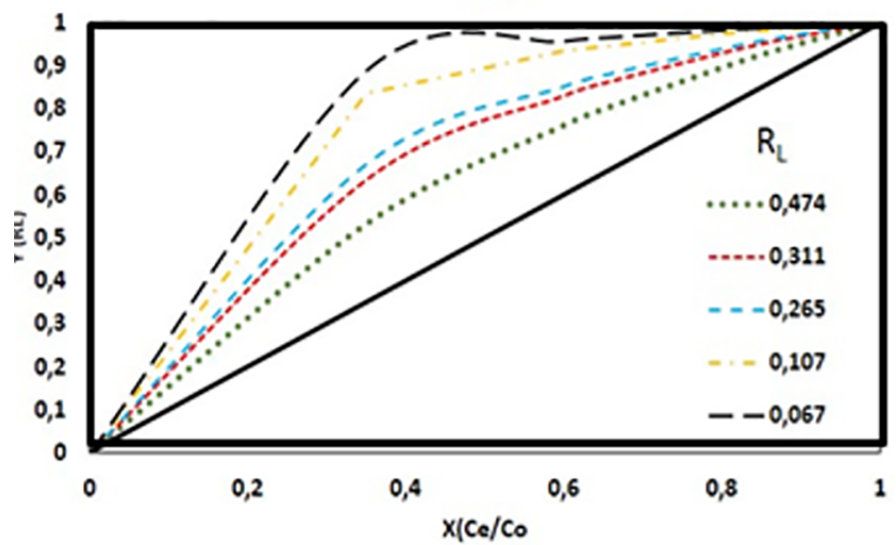

(b)

Figure 3. (a) RL values for the adsorption of $\mathrm{Ca}$ (II) onto CHA adsorbent (b) Adsorption performance curve at $28^{\circ} \mathrm{C}$ as a function of the separation factor for adsorption of $\mathrm{Ca}$ (II) adsorbent in CHA where $\mathrm{Y}$ is according (6) and $\mathrm{X}=\mathrm{Ce} / \mathrm{Co}$

$$
\frac{1}{n}=\frac{R T q_{m}}{\sigma_{0}-\sigma_{1}}
$$

where $\mathrm{qm}$ is the monolayer capacity of the sorbent for the solute, $\sigma_{0}-\sigma_{1}$ is the free energies of the surface covered with pure solvent and with a monolayer of solute, respectively. Although this model is used to describe the adsorption process, its fit to the experimental data does not necessarily imply that only a "pure" adsorption phenomenon has taken place. ${ }^{18,19}$

The estimated parameters of the Freundlich model have been evaluated by both linear regression and non-linear analysis. The results are shown in Table 1. Figure (4) shows the Freundlich isotherm obtained for the $\mathrm{Ca}^{2+}$ (synthetic batch) adsorption on RCA by the linear method. For the CHA adsorbent, the $\mathrm{k}_{\mathrm{F}}$ and $\boldsymbol{n}$ values were found to be 6.52 and 4.11 , respectively. The numerical value of $n>$ 1 represents a favourable adsorption. Figure (5) shows the theoretical data and experiment data.

\subsubsection{The Tenkim isotherm model}

The Temkin isotherm equation assumes that the heat of adsorption of all the molecules in the layer decreases linearly with coverage due to adsorbent-adsorbate interactions, ${ }^{19}$ and that the adsorption is characterized by a uniform distribution of the binding energies up to some maximum binding energy. The Temkin model is given by (10) and in linearized form (11):

$$
\begin{aligned}
& \theta=\frac{R T}{\Delta Q} \ln \left(K_{T} C_{e}\right) \\
& \theta=\frac{R T}{\Delta Q} \ln \left(K_{T}\right)+\frac{R T}{\Delta Q} \ln \left(C_{e}\right)
\end{aligned}
$$

where $\theta$ is the fractional coverage (qe/ $\left.q_{m}\right)$, $\mathrm{R}$ the universal gas constant $\left(\mathrm{J} \cdot \mathrm{mol}^{-1} \mathrm{~K}^{-1}\right), \mathrm{T}$ the temperature $(\mathrm{K}), \Delta \mathrm{Q}=(-\Delta \mathrm{H})$ the variation of adsorption energy $\left(\mathrm{J} \cdot \mathrm{mol}^{-1}\right)$, and $\mathrm{k}_{\mathrm{T}}$ is the Temkin equilibrium constant $\left({\mathrm{L} . \mathrm{mg}^{-1}}^{-1}\right.$ ). By the linear method, the $\Delta H$ value found was -15.77 kJ. $\mathrm{mol}^{-1}$ and $\mathrm{k}_{\mathrm{T}}$ was $0.75 \mathrm{~L} . \mathrm{mg}^{-1} . \Delta \mathrm{H}<0$ 
indicates that $\mathrm{Ca}(\mathrm{II})$ adsorption onto $\mathrm{CHA}$ adsorbent is a exothermic process. Figure (6) shows that the theoretical data have a very good agreement with the experiment data. In Table 1, the Temkin parameters are shown using linear and nonlinear methods.

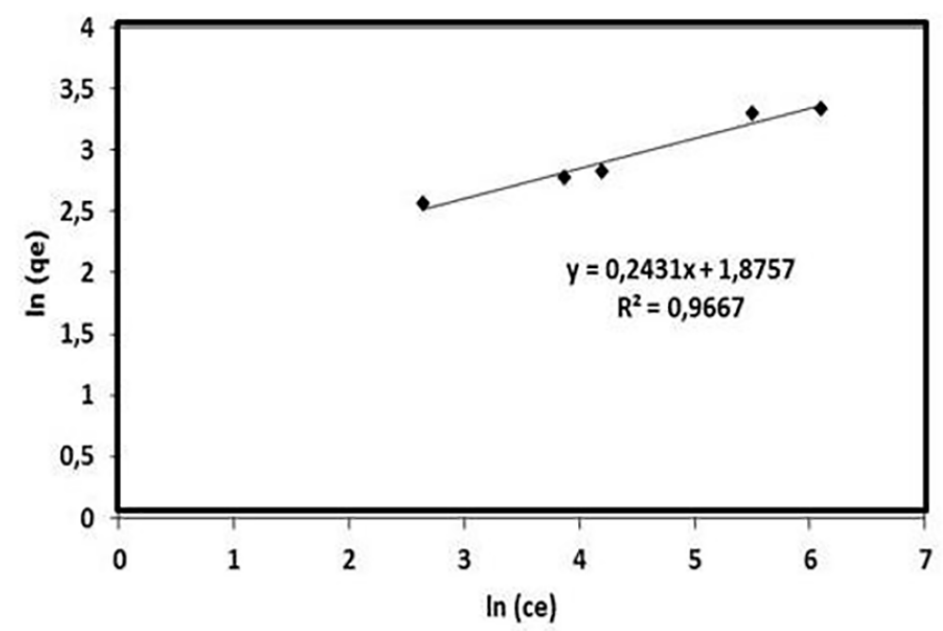

Figure 4. Freundlich isotherm linearized of $\mathrm{Ca}$ (II) adsorbed onto $\mathrm{CHA}$

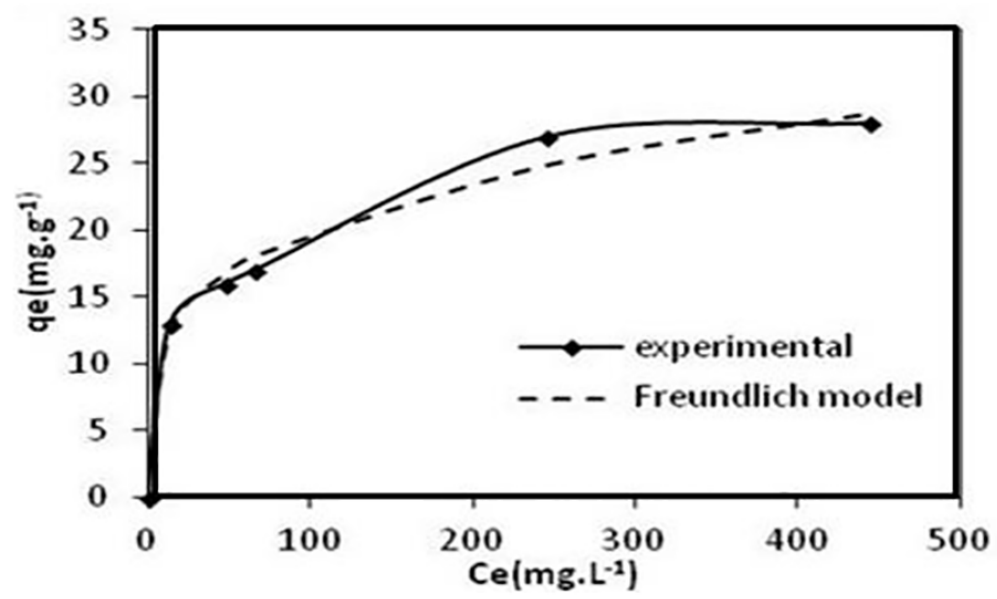

Figure 5. Linear method: theoretical data and experiment data

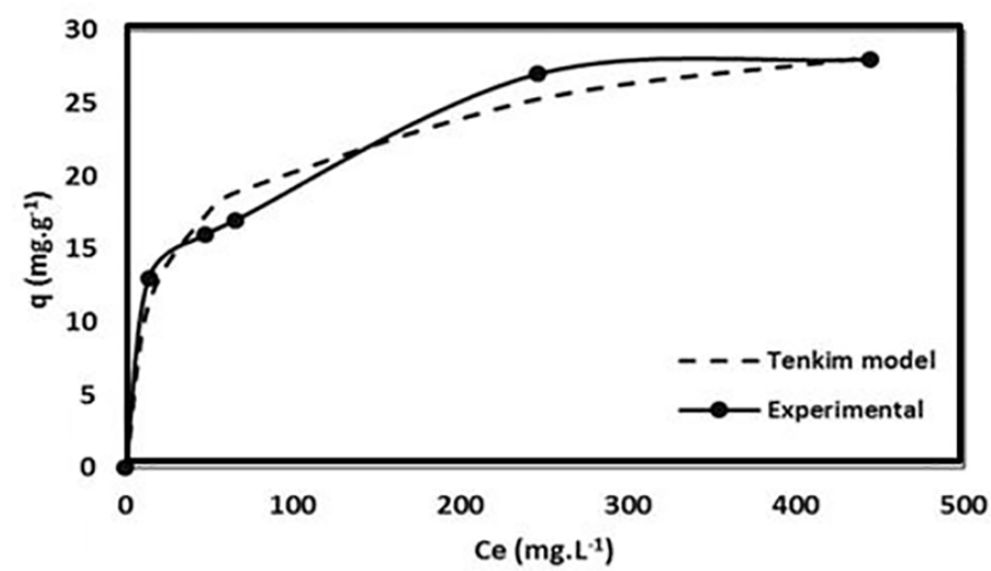

Figure 6. Temkin linear model: theoretical data and experiment data 
Table 1 shows the maximum $\mathrm{Ca}$ ion adsorption capacity of mercerized coconut husk (CHA) and of some adsorbents found in the literature. In Table 1, it is verified that the mercerized coconut husk presented a good capacity of adsorption for calcium ion in relation to other adsorbents found in the literature.

Table 1. Langmuir, Freundlich, and Temkin Models. Parameters for Adsorption of $\mathrm{Ca}$ (II) (Synthetic Batch) onto CHA adsorbent

\begin{tabular}{|c|c|c|c|c|}
\hline Models & qe experimental & Parameters & Linear & Non Linear \\
\hline \multirow[t]{4}{*}{ Langmuir } & 28.00 & $\mathrm{q}_{\mathrm{e}}\left(\mathrm{mg} \cdot \mathrm{g}^{-1)}\right.$ & 30.30 & 30.20 \\
\hline & & $\mathrm{k}_{\mathrm{L}}\left(\mathrm{mg} \cdot \mathrm{L}^{-1}\right)$ & $2.77 \times 10^{-2}$ & $2.87 \times 10^{-2}$ \\
\hline & & $\mathrm{R}^{2}$ & 0.995 & 0.992 \\
\hline & & $\chi^{2}$ & & 2.70 \\
\hline \multirow[t]{4}{*}{ Freundlich } & 28.00 & $\mathrm{n}$ & 4.11 & 4.05 \\
\hline & & $k_{F}\left(m g^{1(-1 / n)} L^{1 / n} g^{-1}\right)$ & 6.52 & 6.42 \\
\hline & & $R^{2}$ & 0.967 & 0.999 \\
\hline & & $\chi^{2}$ & & 0.32 \\
\hline \multirow[t]{4}{*}{ Temkin } & 28.00 & $\Delta \mathrm{H}\left(\mathrm{kJ} . \mathrm{mol}^{1}\right)$ & -15.77 & -15.82 \\
\hline & & $\mathrm{k}_{\mathrm{T}}\left(\mathrm{L} \cdot \mathrm{mg}^{-1}\right)$ & 0.75 & 0.78 \\
\hline & & $R^{2}$ & 0.941 & 0.979 \\
\hline & & $\chi^{2}$ & & 0.021 \\
\hline
\end{tabular}

\subsection{Qui-square $\left(\chi^{2}\right)$ : Analysis of Nonlinear Regression}

The difference in the axial settings of linear equations (of individual isotherm models) will alter the result of a linear regression process, thereby influencing the determination of the model parameters. Whereas, in the nonlinear $\chi^{2}$-analysis suggested by $\mathrm{Ho}^{20}$ all isotherms are being compared on the same abscissa and ordinate, thus avoiding such errors of linearization. The equivalent mathematical statement is (11).

$$
\chi^{2}=\sum \frac{\left(q_{\text {exp }}-q_{c a l}\right)^{2}}{q_{c a l}}
$$

So, if data from the model were similar to the experimental data, $\chi^{2}$ would be a small number and vice versa.

The minimum values of $\chi^{2}$ found for the Temkin $\left(\chi^{2}=0.021\right)$ and Freundlich $\left(\chi^{2}=0.32\right)$ and Langmuir models $\left(\chi^{2}=2.70\right)$ also suggests the best correlation between the model and experimental data. It is clear that all isotherm models suggest an enhanced uptake of $\mathrm{Ca}$ (II) by $\mathrm{CHA}$ adsorbent. However, it is verified in Table 1 that the Temkin model was the one that best described the adsorption process (for the experimental conditions studied), because it presented the lowest error according to the nonlinear regression analysis $\left(x^{2}=0.021\right)$.

\subsection{Kinetic and mechanism study}

The effects of contact time on biosorption of $\mathrm{Ca}$ (II) by $\mathrm{CHA}$ are shown in Figure (7). The amount of $\mathrm{Ca}$ (II) biosorbed increased with an increase in contact time, and equilibrium was reached after $15 \mathrm{~min}$.

Figure (7) shows the effect of contact time on batch adsorption of $85 \mathrm{mg} \cdot \mathrm{L}^{-1}$ at $30{ }^{\circ} \mathrm{C}$. The amount of adsorption sharply increases with time in the initial stage (0-6 min range), and then gradually increases to reach an equilibrium value in approximately $15 \mathrm{~min}$. A further increase in contact time had a negligible effect on the amount of adsorption. According to these results, the agitation time was fixed at $40 \mathrm{~min}$ for the rest of the batch experiments to make sure 
that the equilibrium was reached. The rapid adsorption of $\mathrm{Ca}$ (II) in the first minutes $(<2 \mathrm{~min}$ ) can be attributed to the availability of a large number of vacant surface sites on fresh CHA. The adsorption rate gradually decreases during the adsorption process until the equilibrium is reached. The decreasing $\mathrm{Ca}$ (II) adsorption rate is perhaps due to the slow pore diffusion of $\mathrm{Ca}$ (II) ions into the bulk of CHA.

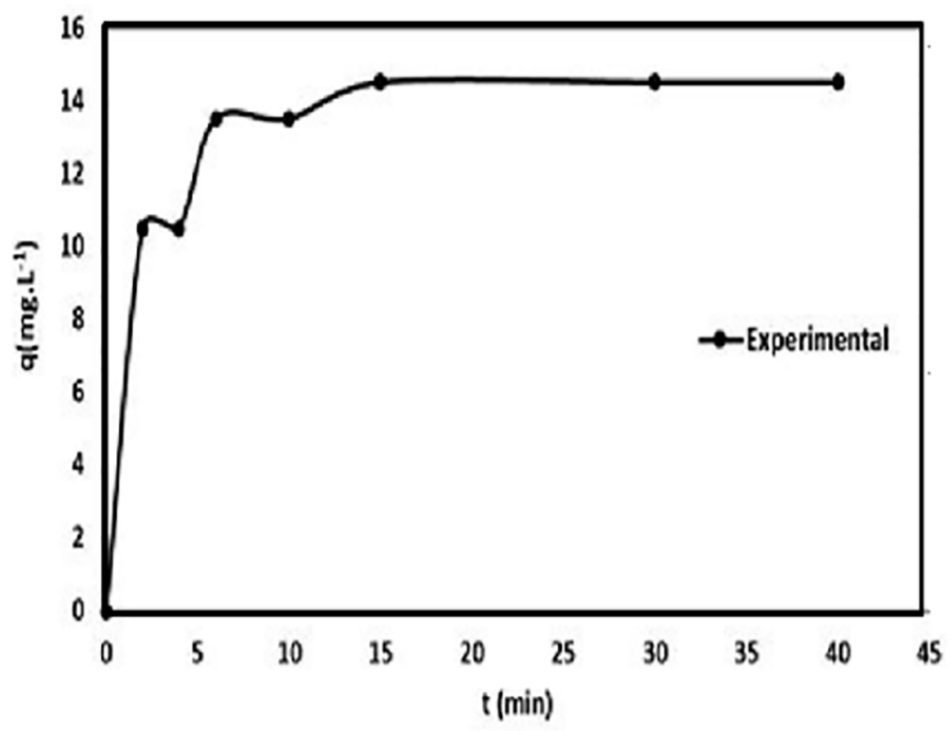

Figure 7. The variation in the amount of adsorption of $\mathrm{Ca}$ (II) with time for $85 \mathrm{mg} . \mathrm{L}^{-1}$ concentration at $30{ }^{\circ} \mathrm{C}$. Conditions: adsorbent dose, $2 \mathrm{~g} . \mathrm{L}^{-1}$; speed, $150 \mathrm{rpm}$; $\mathrm{pH}=6.8$; temperature, $30^{\circ} \mathrm{C}$

\subsubsection{Kinetic models}

In order to determine the kinetic parameters of $\mathrm{Ca}(\mathrm{II})$ adsorption on the $\mathrm{CHA}$, the kinetic models including the pseudo-firstorder, pseudo-second-order, and Elovich equations were applied to fit the experimental data by non-linear regression. The calculated results of the fits are listed in Table 2

\subsubsection{The Elovich equation}

The Elovich equation assumes that the actual solid surfaces are energetically heterogeneous and that neither desorption nor interactions between the adsorbed species could substantially affect the kinetics of adsorption at low surface coverage. The crucial effect of the surface energetic heterogeneity on adsorption equilibrium in the gas/solid systems has been demonstrated, ${ }^{21}$ but the extension of the same to a liquid/solid system is not known.
The Elovich equation ${ }^{22,23}$ is generally expressed as (12):

$$
\frac{d q_{t}}{d t}=\propto \exp \left(-\beta q_{t}\right)
$$

On integration, the Elovich rate equation with boundary conditions $\mathrm{q}=\mathrm{q}_{\mathrm{t}}$ at $\mathrm{t}=\mathrm{t}$ and $\mathrm{q}=0$ at $\mathrm{t}=0$ becomes (13):

$$
q_{t}=\frac{1}{\beta} \ln (1+\alpha \beta t)
$$

where $q_{\mathrm{t}}$ is the sorption capacity at time $\mathrm{t}(\mathrm{mg}$ $\left.\mathrm{g}^{-1}\right), \alpha$ is the initial sorption rate $\left(\mathrm{mg} \mathrm{g}^{-1} \mathrm{~min}^{-1}\right)$, and $\beta$ is the desorption constant $\left(\mathrm{g} \cdot \mathrm{mg}^{-1}\right.$ ) during any one experiment. The initial adsorption rate (Elovich $\alpha$ ) had values of 1071 $\mathrm{mg}$ (g.min) ${ }^{-1}$, and the desorption coefficient (Elovich $\beta$ ) was $0.68 \mathrm{mg} \cdot \mathrm{L}^{-1}$. Figure (8) shows that theoretical data from the Elovich model had very good agreement with the experimental data. In Table 2, the Elovich parameters are shown using nonlinear methods. 


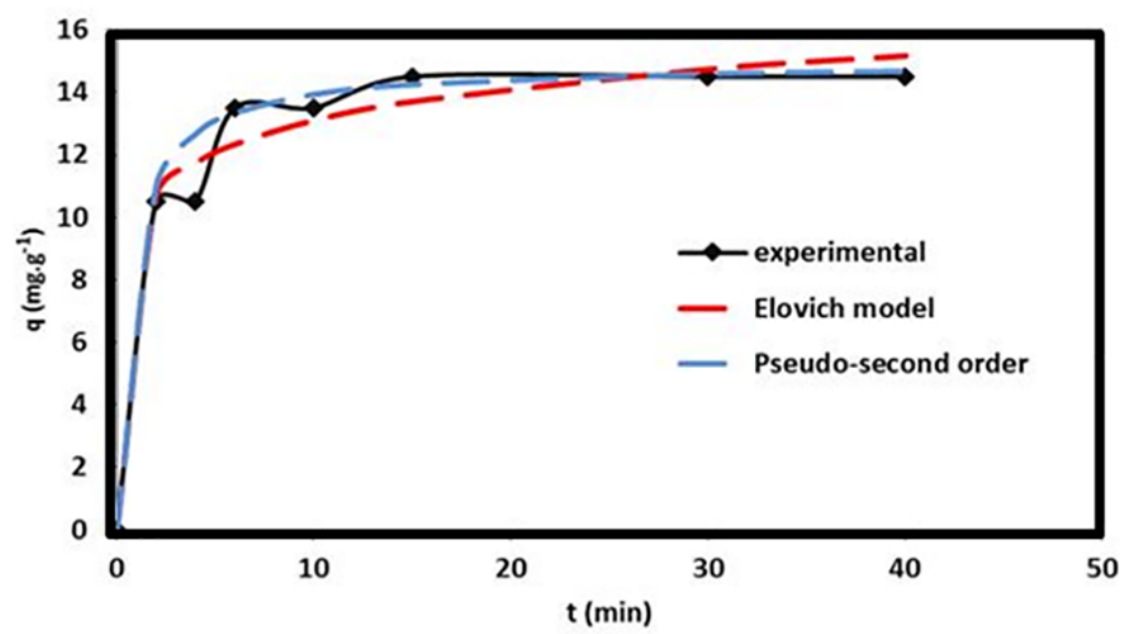

Figure 8. Kinetic models for adsorption of $\mathrm{Ca}(\mathrm{II})$. Comparison of experimental and predicted kinetic models. Experimental conditions: adsorbent dose, 2 g. $\mathrm{L}^{-1}$; speed, $150 \mathrm{rpm} ; \mathrm{pH}=6.8$; temperature, $30^{\circ} \mathrm{C}$

\subsubsection{Pseudo-second order}

The rate of the pseudo-second-order reaction is dependent on the amount of solute adsorbed on the surface of the adsorbent and the amount adsorbed at equilibrium. The pseudo-second-order model can be represented in the following form:

$$
\frac{d q_{t}}{d t}=k_{2}\left(q_{e}-q_{t}\right)^{2}
$$

where $k_{2}$ is the rate constant of pseudosecond-order model $\left(\mathrm{g} \cdot \mathrm{mg}^{-1} \cdot \mathrm{min}^{-1}\right) \cdot \mathrm{k}_{2}$ often depends on the applied operating conditions, namely, initial metal concentration, $\mathrm{pH}$ of solution, temperature and agitation rate. After integrating (19) for boundary conditions, $\mathrm{qt}=0$ at $\mathrm{t}=0$ and $\mathrm{qt}=\mathrm{qt}$ at $\mathrm{t}=\mathrm{t}$, the following non-linear form (20) can be obtained:

$$
q_{t}=\frac{k_{2} q_{e}^{2} t}{1+k_{2} q_{e} t}
$$

Adsorption of $\mathrm{Ca}$ (II) on $\mathrm{CHA}$ reached equilibrium within 15 min (Fig. 6). In Table 3, it is shown that the rate coefficient decreased with increasing initial metal ion concentration. The order rate coefficient, $\mathrm{k}_{2}$, for $\mathrm{Ca}$ (II) was $9.65 \times 10^{-2}$. The constants $k_{2}$ and qe determined from the model are shown in Table 2 along with the corresponding correlation coefficients and error function $\chi^{2}$. Figure (8) shows that theoretical data from the pseudo second order model had a very good agreement with the experimental data. The pseudo second order parameters using nonlinear methods are shown in Table 2.

The half-adsorption time $t_{1 / 2}$ is another parameter which can be calculated from the

Table 2. Comparison of the first and second-order equations and the Elovich equation

\begin{tabular}{|c|c|c|c|c|c|}
\hline \multicolumn{6}{|c|}{ Kinetics parameters } \\
\hline $\begin{array}{l}\text { Models Pseudo second } \\
\text { ordem }\end{array}$ & qe $\left(\mathrm{mg} \mathrm{g}^{-1}\right)$ & qe (experimental) & $\begin{array}{c}k_{2} \\
\text { g.(mg.min })^{-1}\end{array}$ & $\mathbf{R}^{2}$ & $\chi^{2}$ \\
\hline $85\left(\mathrm{mg} \cdot \mathrm{L}^{-1}\right)$ & 14.37 & 14.5 & $9.65 \times 10^{-2}$ & 0.999 & 0.37 \\
\hline \multirow[t]{2}{*}{$\begin{array}{l}\text { Elovich equation } 85 \\
\text { (mg.L-1) }\end{array}$} & $\alpha \mathrm{mg} \cdot(\mathrm{g} \cdot \mathrm{min})^{-1}$ & $\beta\left(m g \cdot g^{-1}\right)$ & & $\mathrm{R}^{2}$ & $\chi^{2}$ \\
\hline & 1041 & 0.68 & & 0.999 & 0.33 \\
\hline
\end{tabular}
rate constants and the calculated and experimental qe values 
equilibrium concentration and the diffusion coefficient rate values. This was calculated by using the following equation (16). ${ }^{24}$

$$
t_{1 / 2}=\frac{1}{k_{2} q e}
$$

The values of $t_{1 / 2}$ determined for the tested parameters are given in Table 3 . For the calculation of the $r$ value, it was assumed that the solid phase consists of particles which are spherical in nature. Calculated values of $t_{1 / 2}$ and $D$ are given in Table 3.

The experimental data for the adsorption of the calcium ion onto $\mathrm{CHA}$ treated with the above kinetic models were used to evaluate the controlling mechanism of adsorption processes. The diffusion coefficient for the intra-particle transport of the $\mathrm{Ca}$ (II) was also calculated by using the following relationship (17):

$$
D=\frac{0.03 r^{2}}{t_{1 / 2}}
$$

where $r$ is the radius of the adsorbent particle in centimetres and $D$ is the diffusion coefficient value in $\mathrm{cm}^{2} \cdot \mathrm{min}^{-1}$.

The higher correlation coefficient $\left(R^{2}\right)$ values and low $\chi^{2}$ values confirmed that the adsorption data were well represented by pseudo second order kinetics for the entire adsorption period (Table 2).

\subsubsection{Mechanism study}

The adsorption mechanism for the removal of $\mathrm{Ca}$ (II) may be assumed to involve the following three steps: (a) diffusion of the $\mathrm{Ca}$ (II) through the boundary layer; (b) intraparticle diffusion, and (c) adsorption of the $\mathrm{Ca}$ (II) on the sorbent surface.

Most of the adsorption processes may be described by either the external mass transfer (boundary layer diffusion) or intraparticle diffusion model. The Weber-Morris model is given by (18):

$$
\mathrm{qt}=\mathrm{k}_{\mathrm{d}} \mathrm{t}^{1 / 2}+\mathrm{C}
$$

where $q_{t}$ is the amount of adsorbed metal ions on the biomass at time $\mathrm{t}\left(\mathrm{mg} \cdot \mathrm{g}^{-1}\right)$; $\mathrm{t}$ is the time (min); and $k_{d}$ is the diffusion coefficient in the solid $\left(\mathrm{mg} \cdot \mathrm{g}^{-1} \cdot \mathrm{min}^{-1 / 2}\right)$. The values of $\mathrm{C}$ provide information about the thickness of the boundary layer. In general, the larger the intercept, the greater is the boundary layer effect ${ }^{25}$. If intraparticle diffusion is controlling, then $\mathrm{q}_{\mathrm{t}}$ versus $\mathrm{t}^{1 / 2}$ will be linear, and if the plot passes through the origin, then the rate limiting process is only due to intraparticle diffusion. Otherwise, some other mechanism along with intraparticle diffusion must also be involved. Pore-diffusion plots often show several linear segments. It has been proposed that these linear segments represent porediffusion in pores of progressively smaller sizes $^{26}$. Eventually, equilibrium is reached and adsorption (qe) stops changing with time, and a final horizontal line is established at qe. When points in a group are identified as belonging to a linear segment, linear regression can then be applied to these points, and the corresponding $k_{i d}$ is estimated.

In the equation (18), $\mathrm{k}_{d}\left(\mathrm{mg} \cdot \mathrm{g}^{-1} \cdot \mathrm{min}^{-1 / 2}\right)$ is defined as the intraparticle diffusion rate constant and is related to the intraparticle diffusivity in the following way (19).

$$
k_{d}=\frac{6 q_{e}}{r} \sqrt{\frac{D}{\pi}}
$$

Where $r(\mathrm{~cm})$ is the particle radius, $D$ $\left(\mathrm{cm}^{2} \cdot \mathrm{min}^{-1}\right)$ is diffusion coefficient, and qe (mg. $\mathrm{g}^{-1}$ ) is the solid phase concentration at equilibrium ${ }^{25}$.

Figure (9) is a plot of qt versus $t^{1 / 2}$ that confirms the validity of the linear relationship. The results (summarized in Table 3 ) can be represented by such a linear relationship, but they do not pass through the origin. This indicates that intraparticle diffusion is involved in the sorption process, but it is not the only rate-limiting mechanism and that some other mechanisms are involved. Applying Weber's model in the step (I) (shown in the figure 9) the values of $k_{i d}(I), C(I), D$, and $\mathrm{R}^{2}$ obtained for the plots were $1.75 \mathrm{mg} \mathrm{g}^{-1} \mathrm{~min}^{-}$ $1 / 2,8.0 \mathrm{mg} \mathrm{g}^{-1}, 3.7 \times 10^{-8}\left(\mathrm{~cm}^{2} \cdot \mathrm{min}^{-1}\right)$, and 0.818 , respectively. The break point in the Figure (9) is at $15 \mathrm{~min}$. 


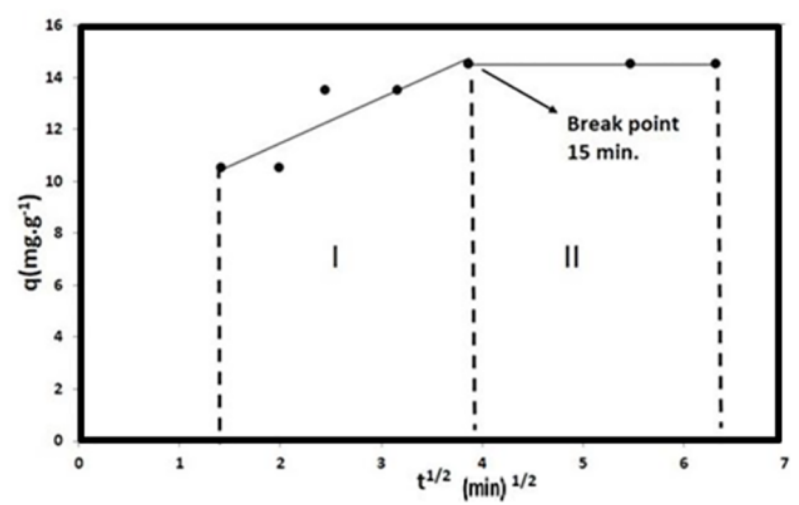

Figure 9. Intraparticle diffusion (from equation 18) plots for the $\mathrm{Ca}(\mathrm{II})$ adsorption on $\mathrm{CHA}$ for initial concentration $85 \mathrm{mg} . \mathrm{L}^{-1}$ and adsorbent dose $=2 \mathrm{~g} . \mathrm{L}^{-1}$ )

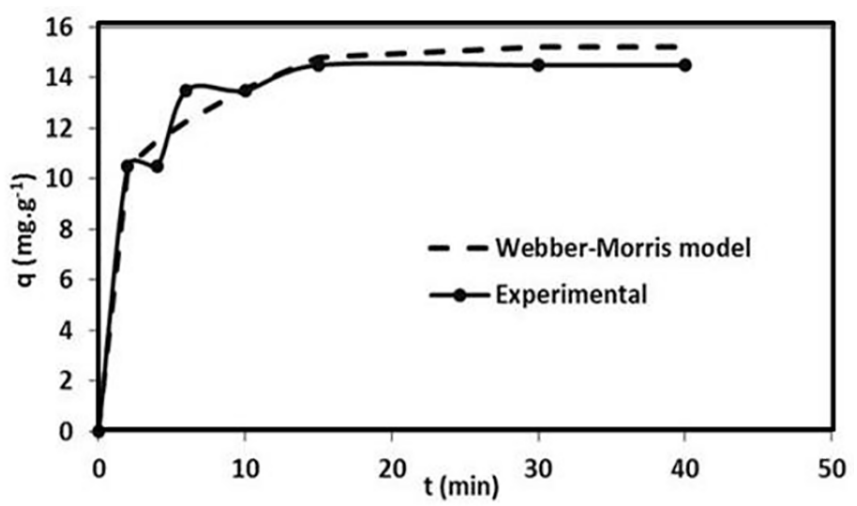

Figure 10. Webber-Morris model and experimental data for the adsorption of $\mathrm{Ca}$ (II) onto CHA. Experimental conditions: $\mathrm{Ca}(\mathrm{II})=85 \mathrm{mg} \mathrm{L}^{-1}$ and adsorbent dose $=2 \mathrm{~g} \mathrm{~L}^{-1}$ )

The first step (I) linear can to be attributed to the intraparticle diffusion states that are highly involved in the rate control of this mechanism. The second step (II) is attributed to the equilibrium stage. It is worth noting the fact that the first linear (step I) plots did not pass by the origin which indicates that intraparticle diffusion is involved in the adsorption process, but it is not the only rate controlling step. In step I the large deviation from the origin shows that the boundary layer diffusion affects the adsorption to some extent (Fig. 9).

Table 3. Diffussion coefficient values for different $\mathrm{Ca}(\mathrm{II})$ concentrations calculated from (17) and (19) considering $r=0.009 \mathrm{~cm}$. $t_{1 / 2}$ was calculated from (17) considering $r=0.009 \mathrm{~cm}$

\begin{tabular}{|c|c|c|c|c|}
\hline \multicolumn{5}{|c|}{ Webber - Morris model } \\
\hline $\mathrm{CO}\left(\mathrm{mg}, \mathrm{L}^{-1}\right)$ & $\mathrm{Kd}$ (mg.g. $\left.\min ^{-1 / 2}\right)$ & C & $\mathbf{R}^{2}$ & $\mathrm{D}\left(\mathrm{cm}^{2} \cdot \mathrm{min}^{-1}\right)$ \\
\hline 85 & 1.75 & 8.0 & 0.818 & $4.60 \times 10^{-6}$ \\
\hline \multicolumn{5}{|c|}{ Diffusion coefficient and $t_{1 / 2}$ from Pseudo second order model } \\
\hline CO (mg.t-1 & $\mathrm{k}_{2} . \mathrm{qe}$ & $\mathrm{t}_{1 / 2}(\min )$ & $\mathrm{D}\left(\mathrm{cm}^{2} \cdot \mathrm{min}^{-1}\right)$ & \\
\hline 85 & 1.39 & 0.71 & $3.42 \times 10^{-6}$ & \\
\hline
\end{tabular}




\section{Conclusion}

The adsorption equilibrium, kinetics, and mechanism have been studied for using a CHA adsorbent to remove hardness. Alkaline treatment was used to modify the surface of coconut bagasse. The removal of as hardness as $\mathrm{Ca}$ (II) from aqueous solution by modified $\mathrm{CHA}$ adsorbent was found to be effective. The adsorption kinetics indicated that the adsorption equilibrium was reached within 15 min under the conditions studied, and that intraparticle diffusion was not the only rate controlling step in the adsorption mechanism. The Elovich equation showed that the adsorption process involved chemisorption. The analysis of the isotherms by the nonlinear model showed that the experimental data were best described by the Temkin model with lower $\left(\chi^{2}=.021\right)$ value was obtained. The maximum adsorption capacity by the Langmuir model was $30.20 \mathrm{mg} \cdot \mathrm{g}^{-1}$. The results using nonlinear and linear methods to study equilibrium showed low discrepancy between them. The results show that the CHA adsorbent can be applied for the removal of hardness from wastewater.

\section{Acknowledgments}

The authors are grateful to Dra. Regina Celia Monteiro de Paula by PZC measurements and Dr. Dr. Ronaldo Ferreira do Nascimento from Department of Physical and Analytical Chemistry both from Federal University of Ceara (UFC). This work was supported by FUNCAP and CNPQ.

\section{References}

${ }^{1}$ Malakootian, M.; Mansoorian, H. J.; Moosazadeh, M. Performance evaluation of electrocoagulation process using iron rod electrodes for removing hardness from drinking water. Desalination 2010, 255, 67. [CrossRef]
${ }^{2}$ Morales-Pinzón, T.; Lurueña, R.; Gabarrell, X.; Gasol, C. M.; Rieradevall, J. Financial and environmental modelling of water hardness - Implications for utilising harvested rainwater in washing machines. Science of the Total Environment 2014, 470-471, 1257. [CrossRef] [PubMed]

${ }^{3}$ NebGuide. Available in: $<$ http://ianrpubs.unl.edu/pages/publicationD .jsp?publicationld=175>. Acessed on: 25 january 2018.

${ }^{4}$ Low, S. C.; Liping, C.; Hee, L. S. Water softening using a generic low cost nanofiltration membrane. Desalination 2008, 221, 168. [Crossref]

${ }^{5}$ Veríssimo, S.; Peinemann, K-V.; Bordado, J.; Membr, J. Influence of the diamine structure on the nanofiltration performance, surface morphology and surface charge of the composite polyamide membranes. Journal of Membrane Science 2006, 279, 266. [CrossRef]

${ }^{6}$ Yildiz, E.; Nuhoglu, A.; Keskinler, B.; Akay, G.; Farizoglu. B. Water softening in a crossflow membrane reactor. Desalination 2003, 159, 139. [CrossRef]

${ }^{7}$ Kabay, N.; Demircioglu, M.; Ersiiz, E.; Kurucaovali, I. Removal of calcium and magnesium hardness by electrodialysis. Desalination 2002, 149, 343 [CrossRef]

${ }^{8}$ Bequet, S.; Abenoza, T.; Aptel, P.; Espenan, J. M.; Remigy, J. C.; Ricard, A. New composite membrane for water softening. Desalination 2000, 131, 299. [CrossRef]

${ }^{9}$ Park, J-S.; Song, J-H.; Yeon, K-H.; Moon, S-H. Removal of hardness ions from tap water using electromembrane processes. Desalination 2007, 202, 1. [CrossRef]

${ }^{10}$ Schaep, J.; Van der Bruggen, B.; Uytterhoeven, S.; Croux, R.; Vandecasteele, C.; Wilms, D.; Van Houtte, E.; Vanlerberghe, F. Removal of hardness from groundwater by nanofiltration. Desalination 1998, 119, 295. [CrossRef]

${ }^{11}$ Bodzek, M.; Koterb, S.; Wesolowsk. K. Application of membrane techniques in a water softening process. Desalination 2002, 145, 321. [CrossRef] 
${ }^{12}$ Yan, M.; Wang, D.; Ni, J.; Qu, J.; Yan, Y.; Chow, C.W.K. Effect of polyaluminum chloride on enhanced softening for the typical organicpolluted high hardness North China surface waters. Separation and Purification Technology 2008, 62, 401. [CrossRef]

${ }^{13}$ Sousa Neto, V. O.; Raulino, G. S. C.; Freire, P. T. C.; Araujo-Silva, M. A.; Nascimento, R. F.; In Book A Book on lon Exchange. 1th ed; $\mathrm{Mu}$ Naushad; Zeid A. Al-Othman, Nova Science Publishers: New York, 2013, cap. 8. [Link]

${ }^{14}$ Vidal, C. B.; Raulino, G. S. C.; Barros, A. L.; Lima, A. C. A.; Ribeiro, J. P.; Pires, M. J. R.; Nascimento, R. F.; BTEX removal from aqueous solutions by HDTMA modified $Y$ zeolite. Journal of Environmental Management 2012, 112, 178. [CrossRef] [PubMed]

${ }^{15}$ Sivakumar, P.; Palanisamy, P. N. Adsorption studies of basic red 29 by a nonconventional activated carbon prepared from euphorbia antiquorum L. International Journal of ChemTech Research 2009, 1, 502. [CrossRef]

${ }^{16}$ Krivova, M. G.; Grinshpan, D. D.; Hedin, N. Adsorption of C TABr surfactants on activated carbons. Colloids and Surfaces A: Physicochemical and Engineering Aspects 2013, 436, 62. [CrossRef]

${ }^{17}$ Sousa Neto, V. O.; Carvalho, T. V.; Honorato, S. B.; Gomes, C. L.; Barros, F. C. F.; Silva, M. A. A.; Freire, P. T. C.; Nascimento, R. F. Coconut bagasse treated by thiourea/amonium solution for cadmium removal: kinetic and adsorption equilibrium. Bioresources 2012, 7,1504 [Link]

${ }^{18}$ Volesky, B.; Biosorption of Heavy Metals. CRC Press: Boca Raton 1992. [Link]

${ }^{19}$ Temkin, M.; Pyzhev, V. Kinetics of ammonia synthesis on promoted iron catalysts. Acta Physiochim URSS 1940, 12, 217. [CrossRef]

${ }^{20}$ Langmuir, I. The constitution and fundamental properties of solid and liquids. Journal of the. American Chemical Society 1916, 38, 2221. [CrossRef]
${ }^{21}$ Rudzinsk, W.; Everett, D. D.; Adsorption of gases on heterogeneous surfaces. Academic Press: London, 1992. [Link]

${ }^{22}$ Rudzinski, W.; Panczyk, T. Adsorption. The Langmuir an Adsorption Kinetics Revised: A Farewell to the XXth. Century Theories 2002, 8, 23. [Link]

${ }^{23}$ Ho, Y. S.; McKay, G. Application of Kinetic Models to the Sorption of Copper(II) on to Peat. Adsorption Science \& Technology 2002, 20, 797.[CrossRef]

${ }^{24}$ Dogan, M.; Ozdemir, Y.; Alkan, M. Dyes Pigm. Adsorption kinetics and mechanism of cationic methyl violet and methylene blue dyes onto sepiolite. Dyes and Pigments 2007, 75, 701. [CrossRef]

${ }^{25}$ Yang, X.; Al-Duri, B. Kinetic modeling of liquidphase adsorption of reactive dyes on activated carbon. Colloid Interface 2005, 287, 25. [CrossRef] [PubMed]

${ }^{26} \mathrm{Ho}$, Y. S. Sorption of dye from aqueous solution by peat. Chemical Engineering Journal 1998, 70, 115. [CrossRef]

${ }^{27}$ Lai, C.; Guo, X.; Xiong, Z.; Liu, C.; Zhu, H.; Wu, M.; Zhang, D. A comprehensive investigation on adsorption of $\mathrm{Ca}$ (II), $\mathrm{Cr}$ (III) and $\mathrm{Mg}$ (II) ions by 3D porous nickel films, Journal of Colloid and Interface Science, 2016, 463, 154. [CrossRef] [PubMed]

${ }^{28} \mathrm{Li}$, G.; Shang, J.; Wang, Y.; Li, Y.; Gao, H. Effect of calcium on adsorption capacity of powdered activated carbon. Journal of Environmental Sciences 2013, 25, 101. [CrossRef]

${ }^{29} \mathrm{Li}$, Q.; Liu, H.; Liua, T.; Guo, M.; Qing, B.; Ye, X.; Wual, Z. Strontium and calcium ion adsorption by molecularly imprinted hybrid gel. Chemical Engineering Journal 2010, 157, 401. [CrossRef]

${ }^{30}$ Medeiros, H. L. S.; Dissertação de Mestrado, Universidade Federal do Rio Grande do Norte, Brasil, 2015. [Link] 